PFI and Port Authorities: Risk identification, Risk allocation and Risk sustainability

\title{
Handley-Schachler and Navare
}

Morrison Handley-Schachler*

Teesside Business School, University of Teesside, Middlesbrough Tees Valley TS1 3BA, UK

E-mail: M.Handley-Schachler@tees.ac.uk

*Corresponding author

\section{Jyoti Navare}

Middlesex University Business School,

The Burroughs, Hendon, London NW4 4BT, UK

E-mail: j.navare@mdx.ac.uk

\begin{abstract}
Ports are complex operations involving government and private-sector partners in creating economic benefits and in identifying, managing and absorbing economic, environmental and security risks. Allocation and assessment of risks is necessitated and facilitated by the diversity of organisations involved. Allocation of the cost of risks among the partners or its transfer to outside agencies through insurance or financing arrangements is essential. However, this allocation is not purely a function of attributes of the risks themselves and their controllability by each of the partners but depends in part on factors such as power structures within partnerships and capacity to absorb risks.
\end{abstract}




\section{PFI and Port Authorities: Risk identification, Risk allocation and Risk sustainability}

\section{Introduction}

Ports are complex combinations of interlocking elements including natural features, infrastructure and superstructure linked through transport connections to other ports and to distribution centres in the hinterland (Juhel 2001). The management of natural resources, infrastructure and superstructure may all be in different hands (de Langen 2004, de Langen and Visser 2005), as well as serving independent logistics businesses who use port facilities (Compés López and Poole 1998).

The participation of public sector authorities is normally necessary, because of the need for environmental protection in the development of natural harbours and subsequent operations and the need for security at national boundaries. Besides, infrastructure is more easily managed in the public sector when extensive planning powers are needed. However, cargo-handling operations and inland transportation links, as well as the shipfping companies who use them and the clients of those companies, are in the main carried out by commercial private-sector companies. Buildings, plant and equipment and services tend also to be more efficiently provided by private commercial organizations.

Some other services, such as customs and public security are, once again, natural functions of the state, because of the lack of sufficient incentives for private sector organizations to take action in the wider public interest. At maritime ports, effectively located at national boundaries, a range of public security services are needed, placing limits on private sector services. Security services may include control of imports of pharmaceuticals, harmful or hazardous substances and alien species, the need for quarantine arrangements for live plants and animals, prevention of illegal arms shipments or shipments of dangerous goods and controls over the movement of individuals involved in organized crime or terrorism or simply illegal immigration.

Because ports are complex operations, which involve interactions between national and international markets, private and governmental operations and the natural and built environment, they are exposed to a very wide range of risks. In addition, because the ownership of different elements of port facilities and of the businesses that use those facilities are all in different hands and because of the impact of events at ports on the external world, a wide range of parties is affected by those risks and the risk may not be directly controllable by those most affected by it. Port-related risks are numerous and include cargo theft (Conley 2000), risks from organized crime and terrorism (Atkinson 2002, p.16) and operational risks such as that suffered by the UK Milford Haven port authority during the Sea Empress incident in 1996 (Navare, 2002) and manpower risks (Saundry and Turnbull, 1999) . The growing business aspect for ports are new partnership arrangements which result in the transference or allocation of risk to partnership parties.

These port and partnership risks provide indications to how risks in broad terms might be identified: risks from operations or sharing of operations; risks from full or partial 
governmental intervention, social and political risks; partnership and co-active collaboration risks. The literature on port and partnership risks, however, is not strong in portraying empirical reality and demonstrating the reality of what constitutes risks to ports.

In the next part we consider the literature on port and partnership risks and attempt to disassociate practical reality of risks from empirical reality to establish key risk categories that affect ports and their partnership arrangements. It is only when this can be achieved then we can begin to evaluate risk allocation and risk sustainability issues for ports and their partnership arrangements.

\section{Studies in port and partnership risk}

\subsection{The theory of port and partnership risk identification}

The studies on port risks have been predominantly based on the practical reality of operations more than by way of empirical explanations. In initially considering the theory of port risks, there is a need to articulate two fundamental questions: first, how have the risks been identified? What have both practitioners and researchers sought to stipulate port risks. This thinking is extended to considering risks arising in partnership arrangements entered in by port authorities.

Second, to what extent are empirical explanations different and substantive over those offered as practical solutions?

\subsubsection{Risk Identification and categorization of port and partnership risks}

Risks in port management can be categorized in a number of ways:

1. By cause, for example, potential human action or potential natural disaster

2. By location of control, i.e. whether the risk can be controlled within the organization concerned or outside the organization or whether it is uncontrollable. This largely depends on the scope of the organization itself and the scope of other organizations. In some cases it may appear natural that a risk-bearing function is carried out outside a commercial organization but the organization may nevertheless take on this task. For example, the need for public security at national boundaries generally necessitates the presence of governmental security forces, although even this can be partly delegated to private warehouses operating under licensing and supervision by customs authorities (Chalfin 2007). On the other hand, apparently integral functions such as signalling and Information Technology management and training can be outsourced and the management of risk transferred to outside contractors (de Langen and Visser (2005).

3. By people affected, owners, employees, customers or others. Again, this may partly depend on organizational and contract structure. For example, risks attaching to property values and property management costs must be borne somewhere but the location of the risk depends essentially on the ownership of the property and the nature and length of leasing and PFI contracts. Jacobs (2003) discusses the issue of leasing publicly owned port land and buildings to private sector firms and the use of 
public scrutiny of tenders for leases of public property in use in the Port of Los Angeles. This can give rise to opportunity costs for the public sector partner, while transferring both risks and opportunities to the private sector, who must bear the risk that the income from the facility does not cover the lease cost while retaining any additional profits made if the lease is underpriced. The degree to which bids are competitive and the length of the lease may be affected by public policy, as it may be difficult to attract bids for shorter term leases if favourable terms are not likely to be offered for a continuation of the contract.

4. By nature of effect, physical injury or loss of welfare. Risks of physical injury to employees and customers are qualitatively different to risks of financial loss, whether to customers, employees or owners and also from loss of amenity resulting from damage to the natural or built environment, even though financial or environmental damage may entail health risks as a further consequence.

5. By location of the effects. Risks relating to harbours may have an effect offshore or inland and these effects may be either on or off the property of the organization with ownership rights in the harbour.

6. By frequency. Risk entails uncertainty, with the level of uncertainty being in part measured by the probability of a particular event occurring on each occasion. Statistically, the frequency of abnormal events with quantifiable effects is measured by kurtosis, with low kurtosis scores (flat distribution) indicating that extreme outcomes are frequent.

7. By degree of effects. Generally, the frequency and the degree of effects must be considered together, as the same type of event with different degrees of effects may occur with different frequencies. For example, a strike involving a single department at a single contractor may occur more frequently than a general strike affecting all port-related industries. The degree of effects may be statistically measured by the use of standard deviations from the mean.Terrorist attacks are a good example of events whose seriousness is in large part a consequence of the size of their potential effects. Although the incidence of attacks is capable of being modelled (Enders and Sandler 2002, Tavares 2004, Enders and Sandler 2006) and has also, overall, been in decline worldwide since the early 1990s (Enders and Sandler 2002, Sandler and Enders 2004), the scale of the largest individual attacks has been increasing and the type and scale of attacks differ widely from year to year (Tilly 2004, Tavares 2004) and between terrorist organizations (Tilly 2004, Barros and Proença 2005).

8. By degree of symmetry, i.e. whether there is upside variability or only a downside and whether the upside is commensurate with the downside. Risks may be considered to be symmetrical when any degree of favourable variation has the same probability as the same degree of adverse variation. This is the case when a) the risk is cause by a variable with a normal distribution pattern and b) the benefits of a unit variation in one direction from the mean expected value are commensurate with the harm caused by a unit variation in the other direction. This may be true, for example, of fuel costs. However, most risk factors are highly skewed, because the best possible outcome, usually consisting of the absence of an event, is the most probable. However, the risk of an adverse event may not be negligible. Therefore the median outcome will be slightly better than the mean. 
9. By level of predictability. Although predictability can relate to the standard deviations, kurtosis and skewness of risk factors and outcomes, it has it also has a great deal to do with the possibility of modelling the effects of causal factors or modelling the causal factors themselves. If the causal factors are too numerous or too greatly dependent on numerous causal factors, it becomes virtually impossible to build reliable models. For example, Williamson (2006) found that the actual progress, establishment and environmental impacts of alien species could be explained in retrospect but could not be predicted with any degree of accuracy. Fowler, T.G., and Sørgård, E. (2000) have also shown that it is possible to model the levels of some types of shipping accidents in general, although this does not mean that individual businesses will be able to model the distribution of losses accurately and modelling of some categories of accident, including groundings, proved harder to model. The control of piracy may also be heavily influenced by local political factors, including corruption and involvement of state officials (Vagg 1995), making medium-term prediction difficult.

Risk identification, allocation and management are vital issues in all projects involving the public sector (Gao and Handley-Schachler 2001), with partnership projects presenting counterparty risks as well as additional opportunities to transfer risks to other partners. These risk categories, however, are considered in absolute terms rather than in relative terms. These risk categorizations intimate objective- level identification of the nature of the risk which can mask the true nature of risk identified. The sorting criteria of risk below unmasks the key attributes and nature of risks in ports management and partnership arrangements.

\subsubsection{Identifying Port risks: practical versus empirical risk factors}

The focus of practitioner observations has been on the extent on visible issues such as: security, environment, operations, management. For example, Bragdon (2007) demonstrated the practical implication of a failed risk identification process. He suggested the need to consider the process and responsibility for risk identification but although the process implications are important the key question on what is the key risks make-up in project management is not considered.

In addition, ports and their related businesses are affected by the usual range of commercial risks relating to supplier capacity and customer demand. Rapid growth in developing countries can make these factors especially unpredictable for organizations generally and for participants in PPPs in particular (Handley-Schachler and Gao 2003).

TABLE AI: IDENTIFICATION OF KEY AREAS OF PORT RISKS

\begin{tabular}{|c|c|c|c|}
\hline Studies & Risk & Practical Studies & Empirical Studies \\
\hline \multicolumn{4}{|c|}{ BY CAUSE } \\
\hline $\begin{array}{ll}- & \text { Spielmann (2007) } \\
\text { - } & \text { Spayd (2006) }\end{array}$ & Security & $\begin{array}{ll}\text { - } & \text { Journal of Commerce } \\
\text { - } & \text { Journal of Commerce }\end{array}$ & \\
\hline $\begin{array}{l}\text { Stanaway, Zalucki, } \\
\text { Gillespie, } \\
\text { Rodriguez, Maynard } \\
(2001)\end{array}$ & Environmental & & $\begin{array}{ll}\text { - } & \begin{array}{l}\text { Australian Journal } \\
\text { of Entomology }\end{array} \\
\text { - } & \text { Risk Management }\end{array}$ \\
\hline
\end{tabular}


- McEwan (1994)

- Christen, (1999; 2004);

- Nunes and van den Bergh (2004),

- Perakis and Yang (2004),

- Machalaba (2005),

- Roberts et al. (2005);

- Batabyal and Beladi (2006);

- Stanaway et al(2001)

\begin{tabular}{|c|c|c|c|}
\hline \multicolumn{4}{|c|}{ BY LOCATION OF CONTROL } \\
\hline - Wang et al (2004) & Operational & & Risk Analysis \\
\hline - $\quad$ Spence $(2005)$ & Commercial & - Canadian Underwriter & \\
\hline $\begin{array}{ll}- & \text { Bragdon (2007) } \\
\text { - } & \text { Mcleod (2001) }\end{array}$ & $\begin{array}{l}\text { Management(inc: } \\
\text { project and process } \\
\text { management) }\end{array}$ & $\begin{array}{ll}- & \text { Defense \& AT-L } \\
- & \text { Business Insurance }\end{array}$ & \\
\hline \multicolumn{4}{|c|}{ BY NATURE OF EFFECTS } \\
\hline $\begin{array}{ll}\text { - } & \text { Kaplan and } \\
\text { - } & \text { Garrick(1981) } \\
& \text { Turnbull \& Wass, } \\
1995\end{array}$ & Financial & & $\begin{array}{ll}\text { - } & \text { Risk Analysis } \\
\text { - } & \text { Public } \\
& \text { Administration }\end{array}$ \\
\hline \multicolumn{4}{|c|}{ BY PEOPLE AFFFECTED } \\
\hline - $\quad$ Turnbull (2006) & Stakeholder & & \begin{tabular}{|ll} 
& British Journal of \\
& Industrial Relations
\end{tabular} \\
\hline $\begin{array}{ll}\text { - } & \text { Larcerda et al } \\
& 1996 \\
\text { - } & \text { Ruquet (2006) }\end{array}$ & Health & & $\begin{array}{ll}- & \text { American Journal of } \\
\text { Public Health } \\
\text { National Underwriter } \\
\text { / Property \& Casualty } \\
\text { Risk \& Benefits } \\
\text { Management } \\
\end{array}$ \\
\hline \multicolumn{4}{|c|}{ BY FREQUENCY } \\
\hline $\begin{array}{c}\text { Ronza(2003); } \\
\text { Wheeler (1993) }\end{array}$ & $\begin{array}{l}\text { Oil tanker } \\
\text { movements; small } \\
\text { boats; loading and } \\
\text { unloading oil, ferry } \\
\text { services; cargo } \\
\text { operations; human } \\
\text { error issues; } \\
\text { accidents; }\end{array}$ & & $\begin{array}{ll}\text { - } & \text { Journal of loss } \\
\text { prevention in the } \\
\text { process industries } \\
\text { - } & \text { Risk analysis }\end{array}$ \\
\hline \multicolumn{4}{|c|}{ BY DEGREE OF SYMMETRY } \\
\hline & $\begin{array}{l}\text { Anti-cyclical } \\
\text { business model }\end{array}$ & Little practical reality & Little empirical reality \\
\hline \multicolumn{4}{|c|}{ BY LEVEL OF PREDICTABILITY } \\
\hline $\begin{array}{c}\text { US Government } \\
\text { Accounting Office } \\
\text { (GAO) (2005) } \\
\text { Woods J (1999) }\end{array}$ & $\begin{array}{c}\text { Risk } \\
\text { determination }\end{array}$ & $\begin{array}{l}\text { Most port organizations } \\
\text { undertake some level of } \\
\text { risk determination } \\
\text { based on predictability } \\
\text { of risk }\end{array}$ & $\begin{array}{l}\text { There is empirical } \\
\text { evidence on financial } \\
\text { risk predictability and } \\
\text { marine security risk }\end{array}$ \\
\hline
\end{tabular}

- Wall Street Journal

- Financial Times
- Environmental Science and technology

- Environmental and Resource Economics

- Marine Economics and Logistics

- European Journal of Operational Research

- Australian Journal of Entomology 
Generally, managers of risk in any context are concerned with a number of issues: risk identification; risk and uncertainty forecasting; risk management; risk impacts, risk allocation and compliance.

Risk identification is part of risk assessment where questions such as what can go wrong; impact outcomes of any risk and what is the potential for impact (Kaplan and Garrick 1981)? The problem with port risks is that what can go wrong is not limited purely to organizational issues such as managerial, operational and security. Furthermore, most of these risks are insurable and therefore are quantifiable and cannot be constituted as the real risk to ports.

\subsubsection{Importance of Partnership Arrangements}

The scale and diversity of capital projects involved in the development of major ports also gives leads to a need for industrial partnership arrangements between different bodies (de Langen 2004) to provide sufficient funds, to furnish the required range of expertise and to co-ordinate the provision of all essential infrastructure, while at the same time guaranteeing sufficient uptake of capacity to make effective use of the infrastructure investment.

Because of the need to co-ordinate different aspects of structural investment and to provide incentives to assess the level of provision needed at different port locations, Public Private Partnerships (PPPs), which may take a variety of forms, involving the creation of public sector infrastructure and basic services to support private-sector service provision, may be a useful mechanism in port development (de Langen 2004, pp.178183). PPPs can allow for the combination of skills from public and private sector partners to provide expertise in a wider variety of functions. They can also enable the creation of a clear client-contractor split, for contract monitoring and control purposes. PPPs can be used as a vehicle to allow Foreign Direct Investment in port infrastructure, especially where suppliers of domestic capital are not willing to commit sufficient financial resources to enable plans to be carried out (Comtois and Dong 2007). Finally, they can, in certain circumstances, be used to improve risk allocation, by seeking to allocate the cost of some risks to the party responsible for causing the risk or best able to manage it. One form of PPP is the Private Finance Initiative (PFI), which can take a variety of forms but involves the provision of assets and services by a private sector partner who is also responsible for financing the assets or services for direct or indirect use in service provision by a public sector partner.

Private sector involvement in the provision of port information systems (Razzaque 1996, p.32, Bagchi and Paik 2001,) and port infrastructure (Wiegmans et al. 2002, Grimsey and Lewis 2005, pp.348-350), through public-private partnerships has been common in recent years, although the financing of infrastructure has ultimately been by the public sector, using taxpayers' money (Wiegmans et al. 2002). The task of the private sector partner has been to provide infrastructure cheaper than the public sector (Grimsey and Lewis 2005), with a strong assumption that it is not possible to make a commercial profit from infrastructure activities (Wiegmans et al. 2002). 
Some services, such as customs and public security are natural functions of the state, because of the lack of sufficient incentives for private sector organizations to take action in the wider public interest. At maritime ports, effectively located at national boundaries, a range of public security services are needed which will place limits on the freedoms of private sector organizations and employees. Reasons for providing these security services include the need to control imports of pharmaceuticals, harmful or hazardous substances and alien species, the need for quarantine arrangements for live plants and animals, prevention of illegal arms shipments or shipments of dangerous goods and controls over the movement of individuals involved in organized crime or terrorism. In addition, controls on the movement of people are maintained to enforce state policies on immigration. Because those potentially affected by security breaches are remote from the port area and because it may not be in the commercial interests of private companies to refuse transport, maintenance of security and enforcement of government policy are best carried out by the public sector.

\subsubsection{Risks in partnership arrangements: practical versus empirical risk factors}

The level of risks involved in PFI contracts and the amount of finance required can be a barrier to entry for smaller private companies (Ezulike et al. 1997). Owen and Merna (1997) also found that risk allocations early on were perceived to be unfair to private sector partners. Bing et al. (2005) found that the majority of respondents to their survey on risk allocation in PFI projects were in favour of most risks being accepted by the private sector partner, with the only real exceptions being risks of government actions directly relating to the project itself. Even risks arising from industrial regulations were felt to be the responsibility of the private sector partner, as they would be in exclusively private sector projects, even though this risk is not controllable for the private sector and is, strictly speaking, controllable by the public sector at the highest level. However, allocations of risk do not always succeed in transferring all risks from the public sector partner, especially where the essentially non-financial risk of failing to deliver a public service are undiminished by the creation of equivalent risks and incentives for the public sector partner (Shaoul 2000; McCabe et al. 2001).

Attempts have been made to draw up a complete scheme of risks to be allocated in Public Private Partnerships by the Private Finance Panel (1995), Gallimore et al. (1997), Akintoye et al. (1998), HM Treasury (2003b), Hodge (2004). These risks include the following general categories:

Risks that arise out of relationships such as organization with organization and organization with stakeholders are difficult to quantify and therefore are difficult to identify. Empirical studies do not effectively account for these risks. We have tried in Table B to sort a rationale for port risk identification

Some financial risks may ultimately be borne by private sector financial institutions involved in funding the project (Asenova and Beck 2003). The public sector partner also tends to accept a higher known cost in return for a reduction in public sector financial risk (Broadbent and Loughlin 2005, p.92; HM Treasury 2003a, p.81; HM Treasury 2003b, pp.85-88). However, this is balanced by a reluctance among public sector bodies to take on activities with some downside but substantial and asymmetric opportunities for profit (Gao and Handley-Schachler 2003). 
The key factor determining the allocation of risk might be expected to be the location of control. However, it may not always be possible to allocate the risk solely on this basis. Firstly, some risks are not controllable by any of the parties, because they are caused by third-party action. Secondly, the effects of the risk may not actually be fully transferable to the party which is best placed to control them (Shaoul 2000). Thirdly, the party responsible for the risk may not have a sufficient incentive to enter into the partnership arrangement if they are not allowed to share their risks.

In addition, some risks which are controlled by government are only controlled to the extent that they are the result of general government and regulatory action which the private sector would, in the normal course of events accept as part of their general business risk. These risks may generally be priced into all contracts. In addition, the provision of state subsidies to cover such risks in the case of companies with government contracts may place these companies at an unfair advantage in bidding for other contracts, as a result of being able to rely on state protection of the profits of their government contracts to survive general economic shocks and thus being able to place a lower price on the risks involved in their private sector contracts. This especially applies to tax and regulatory risks.

TABLE A II: IDENTIFICATION OF KEY AREAS OF PARTNERSHIP RISKS

\begin{tabular}{|c|c|c|c|}
\hline Studies & Risk & $\begin{array}{c}\text { Practical } \\
\text { Studies } \\
\end{array}$ & Empirical Studies \\
\hline \multicolumn{4}{|c|}{ BY CAUSE } \\
\hline & $\begin{array}{l}\text { Regulatory } \\
\text { - Examples: Enforced changes in } \\
\text { construction and service, conditions } \\
\text { of workers' employment, relations } \\
\text { with suppliers and customers, } \\
\text { compulsory insurance, import and } \\
\text { export of goods and services. } \\
\text { - Influences: Legal decisions, } \\
\text { government decisions and decisions } \\
\text { of international treaty organizations, } \\
\text { including United Nations, World } \\
\text { Trade Organization. }\end{array}$ & $\begin{array}{ll}\text { - } & \text { Journal of } \\
\text { - } & \text { Commerce } \\
\text { Journal of } \\
\text { Commerce }\end{array}$ & \\
\hline$\bullet$ & $\begin{array}{l}\text { Environmental } \\
\text { 1. Examples: Effects of the project on } \\
\text { the natural environment, effects on } \\
\text { flora and fauna, } \\
\text { 2. Effects of natural environmental } \\
\text { events on employees, epidemics, } \\
\text { damage to land and buildings from } \\
\text { land erosion or natural disasters. } \\
\text { 3. Influences: Nature of project, } \\
\text { location and natural environment. } \\
\text { Inflation rates, service delivery } \\
\text { timescales, }\end{array}$ & & $\begin{array}{ll}\text { - } & \text { Australian } \\
\text { Journal of } \\
\text { Entomology } \\
\text { - } \text { Risk } \\
\text { Management } \\
\text { - Environment } \\
\text { al Science } \\
\text { and } \\
\text { technology } \\
\text { - Environment } \\
\text { al and } \\
\text { Resource }\end{array}$ \\
\hline$\bullet$ & $\begin{array}{l}\text { Policy } \\
\text { - } \quad \text { Examples: Continued public sector } \\
\text { requirement for services, government }\end{array}$ & & - $\quad$ Risk Analysis \\
\hline
\end{tabular}

Comment [j2]: $\mathrm{MH}$ - would yo be happy to use this grid and fill the studies -s o that I can conclude with the issues on key risk attributes for port and partnership risks 


\begin{tabular}{|c|c|c|c|}
\hline & $\begin{array}{l}\text { support for competing initiatives or } \\
\text { rival regional hubs. } \\
\text { Influences: Changes in party of } \\
\text { government or government } \\
\text { personnel, pressure group action. }\end{array}$ & & \\
\hline$\bullet$ & $\begin{array}{l}\text { - Tax } \\
\text { Examples: Level of taxation of } \\
\text { income, profits, payroll payments or } \\
\text { land use. } \\
\text { - Influences: Government action. }\end{array}$ & $\begin{array}{ll}- & \text { Canadian } \\
& \text { Underwrite } \\
\mathrm{r}\end{array}$ & \\
\hline \multicolumn{4}{|c|}{ BY PEOPLE AFFECTED } \\
\hline$\bullet$ & $\begin{array}{l}\text { Man-made disasters and other human } \\
\quad \text { factors } \\
\text { Examples: Major accidents, } \\
\text { explosions, war, civil strife, } \\
\text { terrorism, organized crime, labour } \\
\text { disputes, sabotage. } \\
\text { Influences: Vulnerability of the } \\
\text { project to specific risks, political } \\
\text { climate, quality of intelligence and } \\
\text { policing. }\end{array}$ & $\begin{array}{ll}\text { - } & \text { Defense \& } \\
& \text { AT-L } \\
\text { - } & \text { Business } \\
& \text { Insurance }\end{array}$ & \\
\hline \multicolumn{4}{|c|}{ BY NATURE, DEGREE AND FREQUENCY OF EFFECTS } \\
\hline \multirow[t]{2}{*}{$\begin{array}{ll}\text { - } & \text { Kaplan and } \\
\text { - } & \text { Garrick(1981) } \\
\text { Bagchi and Paik } \\
\text { (2001) }\end{array}$} & $\begin{array}{l}\text { - Financial } \\
\text { - Examples: Interest rates on } \\
\text { borrowing, ability to refinance } \\
\text { projects at a later date, currency } \\
\text { fluctuations affecting foreign } \\
\text { currency loans. } \\
\text { - Influences: Supply and demand for } \\
\text { loan capital, central bank interest } \\
\text { rates. }\end{array}$ & & $\begin{array}{ll}\text { - } & \text { Risk Analysis } \\
\text { - } & \text { Public } \\
& \text { Administration }\end{array}$ \\
\hline & $\begin{array}{l}\text { - Inflation } \\
\text { Examples: Ability to generate } \\
\text { positive cashflow after inflation. } \\
\text { Influences: inventory levels, } \\
\text { creditor payment periods, debtor } \\
\text { turnover periods. }\end{array}$ & & \\
\hline - $\quad$ Turnbull (2006) & $\begin{array}{l}\text { Demand } \\
\text { Examples: Sufficiency of demand to } \\
\text { cover costs for the private sector or to } \\
\text { create a benefit commensurate with } \\
\text { the cost for the public sector. } \\
\text { Influences: Demand curve, quality, } \\
\text { location and suitability of the service } \\
\text { offered, competition. }\end{array}$ & & \begin{tabular}{|l|} 
British Journal \\
of Industrial \\
Relations
\end{tabular} \\
\hline $\begin{array}{ll}\text { - } & \text { Larcerda et al } \\
& (1996) \\
\text { - } & \text { Ruquet (2006) }\end{array}$ & $\begin{array}{l}\text { Supply-Side } \\
\text { - Examples: Construction time and } \\
\text { cost, ongoing cost of service } \\
\text { provision, service interruptions. } \\
\text { Influences: Efficiency of } \\
\text { construction and service, quality of } \\
\text { construction, supply and demand } \\
\text { for labour, supply and demand for } \\
\text { raw materials, geological factors } \\
\text { and rescue archaeology affecting }\end{array}$ & & $\begin{array}{l}\text { American } \\
\text { Journal of } \\
\text { Public Health } \\
\text { National } \\
\text { Underwriter / } \\
\text { Property \& } \\
\text { Casualty Risk } \\
\text { \& Benefits } \\
\text { Management }\end{array}$ \\
\hline
\end{tabular}




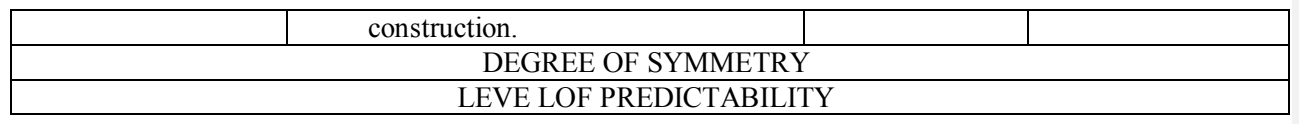

It may also be difficult to establish the cause of losses which may result from a combination of risks. For example, a governmental decision to support competing projects may be influenced by service quality issues which may also affect the competitiveness of the service offered by the PPP.

\subsubsection{Risk Allocation}

Risk allocation involves the shift in resources between the participants in a partnership and in the public private partnership this means risk is allocated or shared between the public and private participants in port management

However in any partnership there is another outside partner and thatis the insurer of psort and partnership risk (see Figure 1)

Risk allocation mechanism involves three factors, pricing risk for allocation, retention of risk and cost of retention and negotiating the volume and types of risks to be allocated. Negotiation involves outside parties such grant providers and insurers. Risk pricing is critical as if risk costs of allocation is high this may lead to discontinuing partnership arrangements or requiring high risk premium in undertaking the risks.

\subsubsection{Risk sustainability}

The sustainability value is based on effective governance structures and risk, quality, performance, culture management structures that demonstrate key benefits to the stakeholders and to the partnership over a sustained period of time.

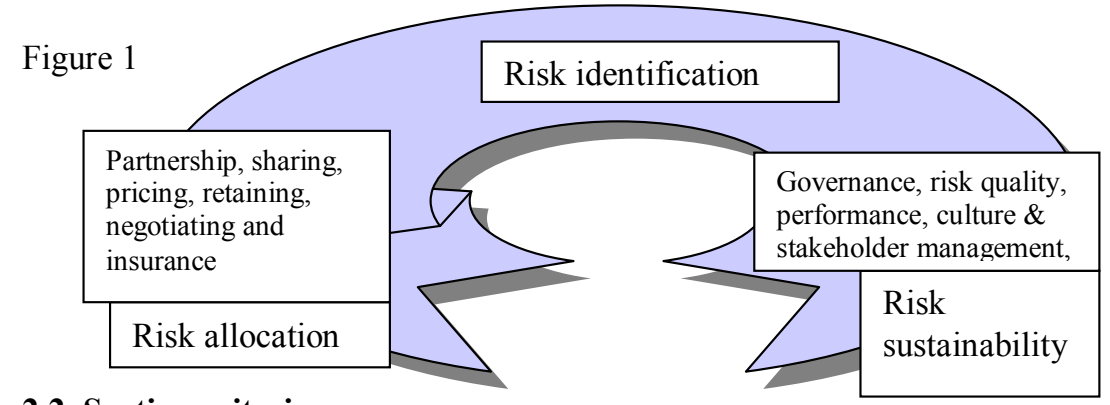

\subsection{Sorting criteria}

It is clear from the risks identified that risks faced by ports are numerous and varied. Although, not yet established some of the risks have higher impact values than others. There is, therefore, a need to categorize the risks and provide some level of justification for the categorization into the three areas of risk identification, allocation and 
sustainability. Empirical evidence is mixed and vague, however, by sorting this it enables the use of this.

TABLE B: SORTING KEY ATTRIBUTES

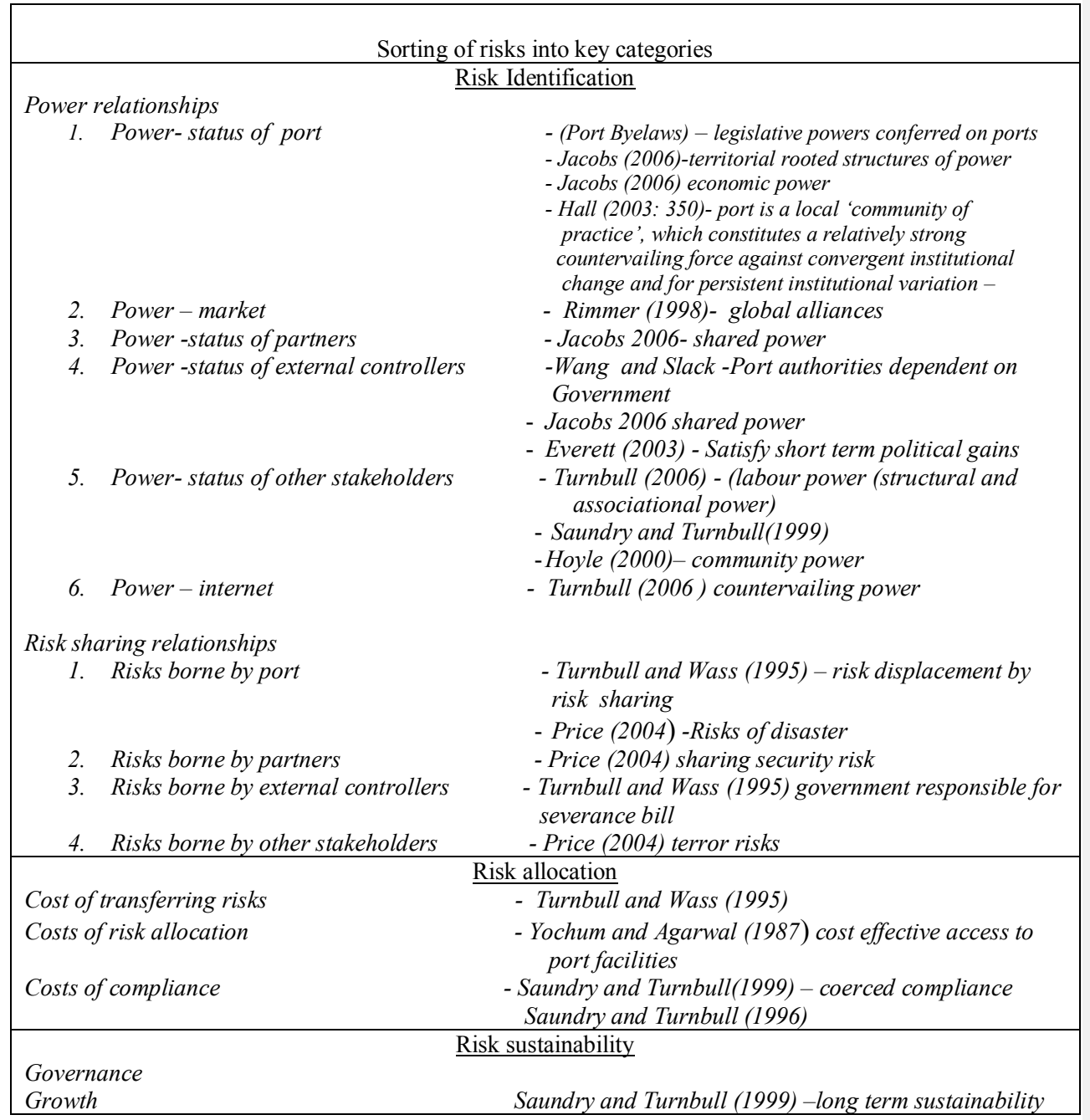

Table B demonstrates that there is really no major discussion on the key aspects of power risk and cost allocation and sustainability. It is clear that most of the issues are considered in what we call a narrow corridor of issues emphasising special risks that heighten impact for port authorities such as terrorist risks and labour group controls. The broad corridor of issues are holistic risk environments such as power domination of ports and risk acceptance status of ports, their partners or stakeholders and the management of cost allocation. These are hardly considered except in special contexts. The problem of risk identification is accentuated when these broad positions are not linked to the specific narrow issues. For example, under a partnership arrangement or government intervention, 
the power of port authorities becomes diluted with implications for cost management and allocation. So the positive of risk allocation is not considered in line with the negative of power dilution, then it becomes difficult to measure the risk

Narrow corridor issues permeate risks to the broader corridor issues. If considering the value of risk allocated, the degree of operational risks arise from power domains and risk allocation modes. Risks arising on crane management may be minimal or significant not only by reason of human error but on how the operations are controlled by whom.

It, therefore, becomes critical to ensure that when identifying risks the broad corridor issues of power, risk and cost risks are considered in line with the risks arising in the narrow corridor.

Furthermore, it needs to be recognized that external demands on the port authorities although the relationship values are more remote can upset risk management capability. We argue that when these attributes of power, risk and cost are evaluated in the context of potentially negative systemic impacts, there is need for a more substantive model of risk identification, allocation and risk sustainability.

\subsection{Model of port and partnership risks}

We argue that the relationship values of power, risk and cost and the relationship of these attributes to the specific attributes of individual port authorities are critical in enabling both risk identification and allocation and eventually the modelling for risk sustainability. Most studies in the both the practical and empirical arena have not considered how the attributes are weighted. For example, power and cost are helpful variables in explaining risk but there are no indicators (weighting factors) as to how helpful or injurious they might be in certain circumstances. Furthermore, it can be seen that studies have provided competing rather than intersectional explanations of power, risk and cost. Xiao-Hua and Doloi (2007) ${ }^{\mathrm{i}}$ suggest the simultaneous considering of commitment and structure in order to develop effective risk allocation strategies.

Bing et al (2004) ${ }^{\text {ii }}$ consider in public - private partnerships to know the importance of which risk factors are best assigned to the public sector and which to the private sector. Their narrow corridor risks subsume power allocations and include nationalization, poor political decision-making process, political opposition, site availability and government stability. They see the sharing of relationship risks, force majeure and legislation change risks by both parties and other risks, predominantly subjective, such as level of public support, project approval, contract variation risks, and experience risks be shared on an individual case basis as these latter risks were not easily allocated. These risks specific to public private partnerships enable risk identification, however the interaction of power, risk and cost considerations enable the identification of specific risk factors affecting specific contexts and organizations. The legitimacy of power theory (Foucault, 1971?), resource dependency theory ( Pieffer, 1981), risk theory and its dependence on human subjective judgments, and the theory of the firm (Coase, 1961) explain the importance of each of these three attributes to organizational theory. However, they do not explain that power, risk and costs can arise irrespective of dependency and remote relationships based on impact rather than on process are equally important. 
Ratcliffe (2004) argued that the use of the PFI increased sustainability, as it required both public and private sector partners to consider properly the whole-life cost of a project, while Gao and Handley-Schachler (2003), found that the PFI encouraged a clear clientcontractor split, enabling greater clarity in the objectives and scope of the project being carried out and avoiding specification creep.

Power relationships are also likely to be a significant factor in the allocation of risks which may result in risks being allocated not to the party best placed to manage them but to the least powerful party.

Finally, there is the question of affordability. The partners with the greatest available resources may need to indemnify the other partners for the cost of adverse events, especially for high impact events which are unpredictable and uncontrollable, in order to enable the project to proceed. Alternatively, external insurance may be sought, where such insurance is economically obtainable.

In conclusion, it is clear that there is no one collective model of risk identification, allocation and sustainability arising from the interactions of power, risk and cost for both port and partnership risks. However, there are ways of viewing risk in term of risk attribute types

Table C: Frameowrk model of port and partnership risks

\begin{tabular}{|c|c|c|c|}
\hline $\begin{array}{c}\text { Risk } \\
\text { Identification } \\
\downarrow\end{array}$ & $\begin{array}{c}\text { Risk } \\
\text { Allocation } \\
\downarrow\end{array}$ & $\begin{array}{c}\text { Risk } \\
\text { Sustainability } \\
\downarrow\end{array}$ & $\begin{array}{c}\leftarrow \text { RISK } \\
\text { ATTRIBUTES } \\
\downarrow\end{array}$ \\
\hline Cause & partnership & Governance & $\leftarrow$ Power \\
\hline Location & insurance & Risk management & \\
\hline Nature of Effects & Risk sharing & Quality management & $\leftarrow$ Risk \\
\hline people affected & Risk pricing & Customer/stakeholder satisfaction & \\
\hline degree of symmetry & Risk retention & Performance management & \\
\hline $\begin{array}{c}\text { Degree of } \\
\text { predictability }\end{array}$ & Negotiation & Culture management & $\leftarrow$ Cost \\
\hline
\end{tabular}

Table $\mathrm{C}$ considers the key attributes of power, risk and cost in relative context of how risks are identified, allocated and sustained. The categorization of risks identified enable a profile of risk which link into the key attributes. For example, risks identified by how people are affected are to do with behavior of pole and their roles and abilities in managing the risk. This in turn involves strategies in risk allocation and ensuring effective outcomes of risk management of port and partnership risks.

\section{Conclusion}

In the theory of port and partnership risks, most of the work empirically and practically considers risk issues in absolute terms rather than considering risks in terms of relative attributes. 
The scale and nature of port operations necessitates the use of partnership arrangements to facilitate the provision of the full range of transport and security services required, with many of these services requiring the involvement of public sector partners. At the same time, port operations involve a considerable number of risks of adverse events, which vary not only in frequency and impact but also in controllability, predictability, symmetry and the parties affected.

In addition, while the ability of different parties to control risks might be expected to be one of the determining factors in risk allocation (HM Treasury 1997, paragraph 3.17), it cannot be expected to be the only factor. Economic dependency may cause the party which is unable to control the risk to accept the cost of the risk in order to obtain the contract, whether they are the service provider or the recipient. In addition, some risks, such as global economic risks are not really controllable by any of the parties, making allocation on the basis of control impossible. Furthermore, where the upside and downside risks are symmetrical or where there are major potential gains on the upside, it may be advantageous for any party to seek to share the risk of loss in return for sharing the potential gains. The parties may also fail to agree on the profile of risks and, in this case, the party which puts the lowest price on the risk may be more likely to accept the risk in preference to paying the other party to bear it.

The risk identification, allocation and sustainability categories were also considered in the context of empirical and practical reality. The key attributes that underlie the true risk in both port and partnership management that are power, risk and cost management realizing on values of negotiating, behavior, processes and managing outcomes

\section{References}

- Akintoye, A., Taylor C. and Fitzgerald, E. (1998). "Risk analysis and management of private finance initiative projects," Engineering, Construction and Architectural Management 5(1): 9-21.

- Asenova, D., and Beck, M. (2003), "The UK financial sector and risk management in PFI projects: A survey," Public Money and Management 23(3):195-202.

- Atkinson, W. (2002), "Great Expectations," Risk Management 49(4): 16-26.

- Bagchi, P.K., and Paik, S.-K., (2001), "The role of public-private partnership in port information systems development," International Journal of Public Sector Management 14(6): 482-499.

- Batabyal and Beladi (2006), "International trade and biological invasions: A queueing theoretic analysis of the prevention problem," European Journal of Operational Research 170(3): 758-770.

- Barros, C.P., and Proença (2005), "Mixed logit estimation of radical Islamic terrorism in Europe and North America," Journal of Conflict Resolution 49(2):298-314.

- Bing, L., Akintoye, A., Edwards, P.J., and Hardcastle, C. (2005), "The Allocation of Risk in PPP/PFI Construction Projects in the UK," International Journal of Project Management 23(1): 25-35.

- Bowers, B. (2005), "On the Storm Front," Best's Review 106(3): 39-43.

- Bragdon, D (2007) The importance of risk identification, Defense \& AT-L; May/Jun2007, Vol. 36 Issue 3, p13-16, 4p, 1 diagram, 1 graph, 2 color 
- Broadbent, J., and Loughlin, R. (2005), “The role of PFI in the UK government's modernisation agenda," Financial Accountability and Management 21(1):75-97.

- Chalfin, B. (2007), "Customs Regimes and the Materiality of Global Mobility: Governing the Port of Rotterdam," American Behavioral Scientist 50(12):1,6101,630 .

- Christen, K. (1999), "Environmentalists, Water Agencies Seek Stricter Controls on Ballast Water Discharges," Environmental Science and Technology 33(7):151A-152A.

- Christen, K. (2004), "UN Sets Treatment Standard for Ballast Water," Environmental Science and Technology 39(9):153A-154A.

- Compés López, R., and Poole, N. (1998), "Quality assurance in the maritime port logistics chain: the case of Valencia, Spain," Supply Chain Management 3(1): 3344.

- Comtois, C., and Dong, J. (2007), "Port Competition in the Yangtze River Delta," Asia Pacific Viewpoint 48(3):299-311.

- Conley, J. (2000), “Hijacked!” Risk Management 47(6): 34-44.

- Department of Shipping (2006), National Maritime Development Programme Port Sector, Ministry of Shipping, Road Transport and Highways, http://shipping.gov.in/writereaddata/linkimages/NMDP2134686903.pdf

- Enders, W., and Sandler, T. (2002), "Patterns of transnational terrorism, 19701999: Alternative time-series estimates," International Studies Quarterly 46(2):145-165.

- Enders, W., and Sandler, T. (2006), "Distribution of transnational terrorism among countries by income class and geography after 9/11," International Studies Quarterly 50(2):367-393.

- Everett (2003) Effective Corporatisation Legislation: The Fundamental Issue in Port Management; Australian Journal of Public Administration 62 (3) , 26-3

- Ezulike, E.I., Perry, J.G., and Hawwash, K. (1997), "The barriers to entry into the PFI market," Engineering, Construction and Architectural Management 4(3):179193.

- Fowler, T.G., and Sørgård, E. (2000), "Modeling Ship Transportation Risk," Risk Analysis 20(2):225-244.

- Gallimore, P., Williams, W., and Woodward, D. (1997). "Perceptions of risk in the private finance initiative," Journal of Property Finance 8(2):164-176.

- Gao, S. and Handley-Schachler, M. (2001), "Need for financial risk management by the public sector: a challenge for the $21^{\text {st }}$ century," Research Supplement to the Public Fund Digest 1(2):67-83.

- Gao, S., and M. Handley-Schachler, M. (2003), "Public bodies' perceptions on risk transfer, in the UK's Private Finance Initiative" Journal of Finance and Management in the Public Services 3(1): 25-39.

- Glaister, S. (1999), "Past abuses and future uses of private finance and public private partnerships in transport," Public Money and Management 19(3):29-36.

- Grimsey, D., and Lewis, M.K. (2005), “Are Public Private Partnerships value for money? Evaluating alternative approaches and comparing academic and practitioner views," Accounting Forum 29: 345-378. 
- Hall, P.V. (2003), Regional Institutional Convergence? Reflections from the Baltimore Waterfront. Economic Geography 79, pp. 347-363.

- Handley-Schachler, M., and Gao, S. (2003), "Can the Private Finance Initiative be used in emerging economies? Lessons from the UK's successes and failures," Managerial Finance 29(576): 36-51.

- HM Treasury (1997), Partnerships for Prosperity, London: HM Treasury Taskforce.

- HM Treasury (2003a), PFI: Meeting the Investment Challenge, HM Treasury, http://www.hm-treasury.gov.uk/media/F/7/PFI_604a.pdf

- HM Treasury (2003b), The Green Book: Appraisal and Evaluation in Central Government, London: The Stationery Office, http://www.hmtreasury.gov.uk/media/3/F/green_book_260907.pdf

- Hodge, G.A. (2004), "The risky business of public-private partnerships," Australian Journal of Public Administration 63(4):37-49.

- Jacobs, W. (2007), "Port Competition between Los Angeles and Long Beach: An Institutional Analysis," Tijdschrift voor Economische en Sociale Geografie 98(3):360-372.

- Hoyle, B (2000); Confrontation, consultation, cooperation? Community groups and urban change in Canadian port-city waterfront; The Canadian Geographer 2000Sep1 Volume 44, Issue 3.

- Juhel, M.H. (2001), "Globalisation, Privatisation and Restructuring of Ports," International Journal of Maritime Economics 3(2): 139-174.

- Kaplan, S., \& Garrick, B. J. (1981). On the quantitative definition of risk. Risk Analysis, 1(1), 11-27.

- Kidd, J., and Stumm, M. (2005), "From Pre-Medieval to Post-Modern times: logistics routes and their modalities have not changed much," Management Decision 43(9): 1,249-1,261.

- De Langen, P. (2004), "Governance in Seaport Clusters," Maritime Economics and Logistics 6: 141-156.

- De Langen, P., and Visser, E.-J. (2005), "Collective action regimes in seaport clusters: the case of the Lower Mississippi port cluster," Journal of Transport Geography 13: 173-186.

- Larcerda, R, Stall, R,Gravato, N,Tellini, R, Hudes, E S,Hearst, N (1996), HIV Infection and Risk Behaviors among Male Port Workers in Santos, Brazil, American Journal of Public Health; Aug 96 Part 1 of 2, Vol. 86 Issue 8, p11581160

- Machalaba, D. (2005), "In Katrina's Wake: New Orleans to Keep Port Shut to Ocean Traffic until Survey," Wall Street Journal, August 31: A6.

- McCabe, B., McKendrick, J. and Keenan, J. (2001). "PFI in schools - pass or fail?" The Journal of Finance and Management in Public Services 1(1):63-74.

- McEwan, B. (1994), "The Loss that Didn't Occur..." Risk Management 41(1): 11.

- Mcleod, D (2001) Port loss claims for asbestos removal; Business Insurance; 05/14/2001, Vol. 35 Issue 20, p6

- Navare J (2001) "Marine oil spill incidents from sea-going tankers: an idiographic study" PhD Thesis Southampton University 
- Nunes, P.A.L.D., and van den Bergh. J.C.J.M. (2004), "Can People Value Protection against Invasive Marine Species? Evidence from a Joint TC-CV Survey in the Netherlands," Environmental and Resource Economics 28(4): 517532.

- Owen, G., and Merna, A. (1997), "The Private Finance Initiative," Engineering, Construction and Architectural Management 4(3):163-177.

- Perakis, A., and Yang, Z. (2004), "Evaluation of the Economic Impact of Proposed Non-Indigenous Species Control Measures for the St Lawrence Seaway Using Multi-Attribute Decision Theory," Marine Economics and Logistics 6(1): 16-33.

- Phillips, M.M., and Crossen, C. (2005), "Will New Orleans Rebound? If Past Disasters are a Guide, the City Will Revive: Chicago, San Francisco, Galveston, Johnstown Rebuilt," Wall Street Journal, September 1: B1.

- Price, W (2004) Reducing the Risk of Terror Events at Seaport; Review of Policy Research 21 (3) , 329-349

- Private Finance Panel (1995), Private Opportunity, Public Benefit, HMSO, London.

- Ratcliffe, A. (2004), "The real benefit of the PFI?" Public Money and Management 24(3):134-135.

- Razzaque, M.A. (1996), "Challenges to logistics development: the case of a Third World country - Bangladesh," International Journal of Physical Distribution and Logistics Management 27(1): 18-38.

- Rimmer, P.J (1998) Ocean liner shipping services: corporate restructuring and port selection/competition; Asia Pacific Viewpoint 39 (2) , 193-208

- Ruquet, M.E (2006), Avian Flu Exposure Could Send Commercial Shipping Off Course

- Roberts, D., Birchall, J., Allison, K., and Yee, A. (2005), "Shippers warn of supply chain chaos," Financial Times, August 31:1.

- Ronza, A (2003 Predicting the frequency of accidents in port areas by developing event trees from historical analysis Journal of loss prevention in the process industries vol:16 iss:6 pg:551

- Sandler, T., and Enders, W. (2004),"An economic perspective on transnational terrorism,” Europäische Zeitschrift für Politische Ökonomie 20(2):301-316.

- Saundry, R and Turnbull, P (1999) Contractual (in) Security, Labour Regulation and competitive performance in port transport industry: A contextualized comparison of Britain and Spain, British Journal of Industrial relations 37:2 pp 271-292

- Shaoul, J., (2000). "Passport to paralysis," Public Finance, July $21^{\text {st. }}-27^{\text {th. }}$, pp. 20-21.

- Shine, C. (2007), "Invasive species in an international context: IPPC, CBD, European Strategy on Invasive Alien Species and other legal instruments," European and Mediterranean Plant Protection Organization Bulletin 37(1):103113.

- Spayd, P (2006) Serious about port security? Journal of Commerce; 11/13/2006, Vol. 7 Issue 46, p58. 
- Spence, V (2005) Port in the storm, Canadian Underwriter Mar2005, Vol. 72 Issue 3, p16-17

- Stanaway, M.A, Zalucki, M.P; Gillespie,P.S; Rodriguez, C.M; and Maynard, G.V (2001) Pest risk assessment of insects in sea cargo containers Australian Journal of Entomology 40 (2), 180-192.

- Tavares, J. (2004), "The open society assesses its enemies: shocks, disasters and terrorist attacks," Journal of Monetary Economics 51(5):1,039-1,070

- Tilly, C. (2004), "Terror, terrorism, terrorists," Sociological Theory 22(1):5-13.

- UNCTAD (2004), Review of Maritime Transport 2004, Geneva: United Nations Conference on Trade and Development.

- United States Government Accounting Office (2005), Risk Management: further refinements needed to assess risk and prioritize protective measures at Ports and other critical infrastructure; Report to Congressional Requesters December 2005

- Turnbull, P and Wass, V (1995) The great dock and dole swindle: Accounting for the costs and benefits of port transport deregulation and dock labour compensation scheme Public Administration, Winter 95, Vol. 73 Issue 4, p513534 ,

- Turnbull, $\mathrm{P}(2006)$ The War on Europe's Waterfront - Repertoires of Power in the Port Transport Industry, British Journal of Industrial Relations 44 (2) , 305326

- Vagg, J. (1995), "Rough seas: Contemporary piracy in South East Asia," British Journal of Criminology 35(1):63-80.

- Wang, J, Sii, H.S, Yang, J.B, Pillay, A; Yu, D, Liu, J, Maistralis, E Saajedi, A (2004) Use of Advances in Technology for Maritime Risk Assessment, Risk Analysis 24 (4) , 1041-1063

- Wang, J.J and Slack, B (2004)Maritime Policy and Management; Oct-Dec2004, Vol. 31 Issue 4, p357-373

- Wheeler, T.A (1993) Risk-Based Ranking of Dominant Contributors to Maritime Pollution Events, Risk Analysis [0272-4332] vol:13 iss:2 pg:207

- Wiegmans, B.W., Ubbels, B., Rietveld, P., and Nijkamp, P. (2002), "Investments in Container Terminals: Public Private Partnerships in Europe," International Journal of Maritime Economics 4: 1-20.

- Williamson, M. (2006), "Explaining and predicting the success of invading species at different stages of invasion," Biological Invasions 8(7):1,561-1,568.

- Wood, J (1999), Ocean Predictability, Anton Bruun Memorial Lecture Presented Unesco House Paris 30. June 1999

- Yochum, GR and Agarwal V.B(1987); Economic impact of port on regional economy, Growth and Change Summer 1987 Vo.18 iss 3 
i Risk Allocation in Public - Private Partnership Projects - An Innovative Model With and Intelligent Approach20 September 2007Mr. Xiao-Hua Jin, Research Scholar Dr. Hemanta K. Doloi, Lecturer Faculty of Architecture Building and Planning, The University of Melbourne Parkville

ii

Risk allocation preferences in PPP/PFI Construction Projects in UK14 September 2004Li Bing, A. Akintoye, P. J. Edwards and C. Hardcastle School of the Built and Natural Environment, Glasgow Caledonian University 